\title{
Histopatology of the reproductive tract of Nellore pubertal heifers with genital ureaplasmosis
}

\author{
REGIANI PÔRTO ${ }^{1}$, BENEDITO OLIVEIRA FILHO ${ }^{1}$, HENRIQUE FERRAZ ${ }^{2}$, LUCIANO \\ CAIXETA $^{3}$, MARCO ANTONIO VIU ${ }^{2}$ and MARIA LÚCIA GAMBARINI ${ }^{1}$ \\ ${ }^{1}$ Escola de Veterinária e Zootecnia, Universidade Federal de Goiás, Campus Samambaia, \\ Avenida Esperança, s/n, Campus Universitário, 74690-900 Goiânia, GO, Brazil \\ ${ }^{2}$ Unidade Especial de Ciências Agrárias, Regional Jataí, Universidade Federal de Goiás, Campus \\ Cidade Universitária, BR 364, Km 195, 3800, 75801-615 Goiânia, GO, Brazil \\ ${ }^{3}$ Veterinary Population Medicine Department, College of Veterinary Medicine, \\ Minessota University, 1365 Gortner Avenue, St. Paul, MN 55108, USA
}

Manuscript received on November 24, 2016; accepted for publication on May 23, 2017

\begin{abstract}
In order to study and characterize the lesions in the reproductive tract of Nellore heifers naturally infected with Ureaplasma diversum and presenting granular vulvovaginitis syndrome (GVS), fragments of uterine tube, uterus, cervix, vagina and vulva of 20 animals were evaluated. The macroscopic lesions of the vulvovaginal mucosa were classified in scores of "1" mild, until "4", severe inflammation and pustular or necrotic lesions. The histopathological evaluation was performed using scores of " 1 " to " 4 ", according to the inflammatory alterations. The fragments with severe microscopic lesions ( 3 and 4 ) were from the uterine tubes and uterus, which showed leukocytes infiltration and destruction and/or necrosis of epithelium. Alterations in the lower reproductive tract fragments were mild, but characteristics of acute inflammatory processes. The histopathological findings of the reproductive tract of females naturally infected with Ureaplasma diversum are consistent with injuries that compromise the environment from the local where spermatozoa acquires ability to fertilize an oocyte until those where the oocyte is fertilized. Therefore, animals with GVS should be identified early in the herd, because, besides the reduction in the fertility rates caused by tissue damages, they can contribute to disseminate the microorganism.
\end{abstract}

Key words: bovine, tissue evaluation, reproduction, Ureaplasma diversum.

\section{INTRODUCTION}

Low calving rates in the beef production systems might be related with female fertility, and the inflammation and infection of reproductive tract act as important factors in this event, because

Correspondence to: Maria Lúcia Gambarini

E-mail: mlgambarini@pq.cnpq.br promote undesirable conditions in the uterus and uterine tube environment (Martins et al. 2002). Injuries in the tissue caused by calving or during artificial insemination, as well as the immunesuppression have major role in the establishment and maintenance of infectious processes of the bovine reproductive system (Bell and Roberts 2007). 
Repeat breeding cows not always show positive results of uterine content for potentially pathogenic or opportunist microorganisms, but always presented some endometrial injuries (Galindo et al. 2004). Even before puberty, bovine females can present positive samples for pathogenic microorganisms in the reproductive system, demonstrating association between the presence of microorganisms of the family Mycoplasmataceae, mainly of the genera Mycoplasma and Ureaplasma, with reduced gestation rates in heifers (Gambarini et al. 2009).

Ureaplasmas are Mollicutes and are one of the smallest free-living microorganisms, and they lack rigid cell wall. They are opportunists, which colonize the reproductive tract of females and males and are involved in the infertility of many species, including humans and bovines, different from the other members of this class due to the ability to hydrolyze urea in carbon dioxide and ammonia, which is one of the responsible factors of the cilliostatic activity of the ureaplasmas. Ureaplasma diversum is the only specie in bovines, causing outbreaks of granular vulvovaginitis syndrome (GVS) and cervicitis (Ahmadi et al. 2006, Husted 2003), followed by abortion and reduction of the reproductive efficiency of the herd (Oliveira Filho et al. 2005).

In Brazil, the first report of the presence of $U$. diversum in vulvovaginal mucus of cows with reproductive disorders was done in 2000, highlighting the importance of the differential diagnosis with other organisms of similar action (Cardoso et al. 2000). In pre pubertal beef heifers the identification of Ureaplasma diversum in the vagina and vestibulum mucus, there was related with delay in the pubertal age, as well as with low pregnancy rates during the first breeding season (Gambarini et al. 2009). Ureaplasma diversum can be detected in IVF-derived embryos (ChełmońskaSoyta et al. 2001), semen (Hobson et al. 2013), in cows with reproductive disorders (Cardoso et al. 2000, Azevedo et al. 2017), and in the uterine content of metritic and healthy cows (Peng et al. 2013, Jeon et al. 2016).

Despite of its simple structure and function, the way that ureaplasmas interact with their host is not totally elucidated, although studies demonstrated that the way of parasitism in the host cell is primarily extra-cellular (You et al. 2006).

Thus, considering the small amount of information about the tissue modifications resulted from natural infections caused by ureaplasmas in bovines the aim of this study was to evaluate the tissue alterations caused by Ureaplasma diversum in the genital tract of pubertal heifers naturally infected, through the histopathological evaluation of the uterine tubes, uterus, cervix, vagina and vulva.

\section{MATERIALS AND METHODS}

LOCAL OF STUDY

The study was conducted in a commercial beef system located in Midlle-West region of Brazil, located at $18^{\circ} 53^{\prime}$ 'south and $50^{\circ} 59^{\prime}$ west, $450 \mathrm{~m}$ a.s.1., annual temperature and precipitation are $24^{\circ} \mathrm{C}$ and $1600 \mathrm{~mm}$, respectively.

\section{ANIMALS, SAMPLING AND CULTURE}

This study was approved by the Ethics Committee in Research with Animals (CEUA) of the Federal University of Goiás.

Fifty Zebu heifers of a lot of 177 were identified with GVS and submitted to vaginal mucus collection, to identify the present microorganisms. The lesions on the surface of vulvovaginal mucosa were examined and scored in four vaginal lesion scores (VLS), according the size and appearance of vesicles, grade of present hyperemia and extension of lesions (Table I, Gambarini et al. 2009).

After the identification of lesions, vaginal mucus was collected by using one sterile swab rubbed on the mucosa. The sample was placed 
TABLE I

Characterization of Vaginal Lesion Score (VLS).

\begin{tabular}{|c|c|}
\hline $\begin{array}{l}\text { Lesion } \\
\text { Grade }\end{array}$ & Description \\
\hline G1 & $\begin{array}{l}\text { Few small vesicles near the clitoris, no } \\
\text { hyperaemia }\end{array}$ \\
\hline G2 & $\begin{array}{l}\text { Many vesicles with a diameter from 1-2 mm } \\
\text { and distributed on the vestibulum mucosa, mild } \\
\text { hyperaemia }\end{array}$ \\
\hline G3 & $\begin{array}{c}\text { Many large vesicles and petechiae distributed } \\
\text { on the mucosa of the vestibulum and vagina, } \\
\text { marked inflammation }\end{array}$ \\
\hline G4 & $\begin{array}{c}\text { Pustules and/or necrotic lesions and severe } \\
\text { inflammation }\end{array}$ \\
\hline
\end{tabular}

in $\mathrm{A}_{3 \times \mathrm{B}}$ transport medium (Cunha et al. 1987), maintained at $4{ }^{\circ} \mathrm{C}$ and processed for the isolation of Ureaplasma diversum within 24 hours of collection. In the laboratory aliquots from the transport medium were inoculated in Ub medium, agar Ub, and agar Hayflick, incubated, and evaluated as described by Ruhnke and Rosendal (1994). Tubes and plates were examined daily to assess the urease activity and presence of small dark brown-colored granular colonies characteristic of ureaplasmas. Plates were incubated for 15 days at $37^{\circ} \mathrm{C}, 95 \% \mathrm{~N}_{2}+$ $5 \% \mathrm{CO}_{2}$ and residual $\mathrm{O}_{2}$, and broths were incubated aerobically up 15 days at $37^{\circ} \mathrm{C}$.

After two weeks, heifers identified as positive only for Ureaplasma diversum $(\mathrm{n}=28)$ were slaughtered at the local abattoir and the reproductive tract was taken out in a whole piece. The organs were immediately and aseptically open and samples of mucosa content were taken using swabs, which were maintained in thyoglicolate medium at $4^{\circ} \mathrm{C}$ and used to identify probable presence of other microorganisms. After that it was proceeded the sampling of fragments of uterine tubes (infundibulum, ampulla and isthmus, left and right), uterine horns (left and right, 2 equidistant levels), uterine body, cervix (uterine, medial and vaginal portion), fornix (left and right), vagina and vulva. In the laboratory tissue samples were dehydrated and embedded in paraffin wax. After the confirmation of the heifers, which samples of reproductive tract were negative for any other bacterium, paraffin embedded tissues were sectioned at thickness of $5 \mu \mathrm{m}$ and stained by the haematoxylin-eosin method (HE) according to Luna (1968).

Samples obtained from the mucous of the different parts of reproductive tract were processed for microbiological isolation, according to Mateus et al. (2002). Briefly, aliquots of transport medium were anaerobically (up to 7 days) and aerobically (up to $48 \mathrm{hs)} \mathrm{cultured} \mathrm{on} \mathrm{specific} \mathrm{agars} \mathrm{and} \mathrm{broths.}$ Bacteria were identified by colony morphology and biochemical characteristics.

\section{HISTOPATHOLOGICAL EVALUATION}

The results regarding microbiological evaluation of the material obtained from vaginal lesions and other segments of reproductive tract were analyzed, and only those presenting growth of Ureaplasma diversum alone, and negative cultures in the other parts of reproductive tract were used to study the histopathological status, resulting in material of 19 heifers.

The uterine evaluation was done according to the following inflammatory tissue alterations: limphocitary infiltration, glandular dilation, periglandular fibrosis, epithelium destruction and muscular necrosis, For the evaluation of the fragments of oviducts and cervix sections, fornix, vagina and vulva it was considered the presence of cellular infiltration, kind of infiltrated cells, presence of other inflammatory alterations, loss and/or tissue lesion. For all fragments the degree of lesion was estimated in scores varying from 0-4, were 0 was the total absence of tissue lesion and 4, the presence of at least four of the above mentioned alterations.

The histopathological evaluation was done using an optical microscope (Carl Zeiss ${ }^{\circledR}$, 
Germany) and the microscopic fields photographed by digital camera (Digital Still Camera DSC P-71 Cybershot, SONY®, Manaus, Brazil) attached to the microscope. For slides evaluation and microphotographs the magnitude of 200 and 400X were used.

\section{STATISTICAL ANALYSIS}

The results were analyzed by U-Test (Mann Whitney) and Kruskal-Wallis for non-parametric samples and presented as $\mathrm{M} \pm \mathrm{SEM}$. Differences were considered significant when $\mathrm{P}<0.05$ using the confidence interval of $95 \%$. The statistical analysis was performed using the computational package WinStat 3.1 (2006).

\section{RESULTS}

In all heifers positive for Ureaplasma diversum was possible to verify some degree of characteristic lesion of the GVS, which means, mucosal hyperemia, presence of granules with $1-2 \mathrm{~mm}$, translucent, distributed partly or in all examined area. In some cases it was observed petechiae and necrosis, although without vaginal discharge. Frequencies of macroscopic VLS are in Table II.

From 19 slaughtered heifers there were obtained 294 fragments (Table III), with differences in the microscopic lesion scores $(1-4, \mathrm{P}<0.01)$. The frequencies of histopathological lesion scores divided by organs are in Tables IV and V. The lesions present in all portions of the reproductive tract were considered as severe, because of the presence of widespread inflammatory alterations, such as edema, hyperemia, cellular infiltration, and loss of epithelium or muscular necrosis.

In the fragments of the oviducts the most frequent lesions were the epithelium desquamation with exposure of the basal membrane, formation of clots in the lumen, curvature or absence of the cilium as well as projection of the cytoplasm of many epithelium cells towards the lumen. In the
TABLE II

Frequencies of macroscopic Vaginal Lesion Scores (VLS) in the vaginal mucosa of $\mathbf{1 9}$ heifers positive for Ureaplama diversum.

\begin{tabular}{cc}
\hline Lesion Grade & N (\%) \\
\hline 0 & - \\
1 & $5(26.3)$ \\
2 & $8(42.1)$ \\
3 & $3(15.8)$ \\
4 & $3(15.8)$ \\
Total & $19(100.0)$ \\
\hline
\end{tabular}

TABLE III

Distribution of microscopic lesions in the uterine tube (infundibulum, ampola andisthmus), cervix (uterine, medial and vaginal), vagina and vulva of heifers with GVS and presenting positive culture for Ureaplasma diversum.

\begin{tabular}{ccc}
\hline Anatomical Structure & N & $\begin{array}{c}\text { Means } \pm \\
\text { SEM }\end{array}$ \\
\hline Infundibulum & 19 & $1.4 \pm 0.2^{\mathrm{a}}$ \\
Ampulla & 23 & $1.9 \pm 0.2^{\mathrm{a}, \mathrm{b}}$ \\
Isthmus & 26 & $2.4 \pm 0.3^{\mathrm{b}, \mathrm{c}, \mathrm{d}}$ \\
Anterior Uterine horn & 28 & $4.0^{\mathrm{c}, \mathrm{d}}$ \\
Medial Uterine Horn & 33 & $4.0^{\mathrm{d}}$ \\
Uterine Body & $15^{* *}$ & $2.9 \pm 0.4^{\mathrm{c}, \mathrm{d}}$ \\
Uterine Cervix & $18^{* *}$ & $3.5 \pm 0.2^{\mathrm{d}}$ \\
Medial and Vaginal Cervix & 31 & $2.9 \pm 0.2^{\mathrm{c}, \mathrm{d}}$ \\
Fornix Vagina & 33 & $2.8 \pm 0.2^{\mathrm{b}, \mathrm{c}, \mathrm{d}}$ \\
Vagina & $16^{* *}$ & $3.0 \pm 0.3^{\mathrm{c}, \mathrm{d}}$ \\
Clitoris & $18^{* *}$ & $2.9 \pm 0.3^{\mathrm{b}, \mathrm{c}, \mathrm{d}}$ \\
Vulva & 34 & $2.5 \pm 0.2^{\mathrm{a}, \mathrm{b}, \mathrm{c}}$ \\
Total & 294 &
\end{tabular}

Infundibulum, ampulla, isthmus, uterine horns and fornix vagina - left and right. **Only one fragment. Small letters in the same column indicate differences $(\mathrm{P}<0.01)$ (KruskalWallis).

uterine horns and body the lesions were also severe, and the medial portion was mostly injured, but there was no difference between lesions scores (Table IV). The most frequent lesions were destruction of the cilium of the epithelial cells and areas of 
ulceration; destruction of the glandular epithelium with lymphocytes infiltration; edema, conjunctive proliferation, lymphocytes/neutrophils infiltration and the presence of eosinophils in the submucosa, as well as necrosis of muscular fibers.

In the cervix, the lesions verified were equally severe (Table V), without difference between the three segments (uterine, medial and vaginal). The presented alterations varied since the accumulation of eosinophils and leukocytes and epithelial lesion until the presence of edema, hyperemia, cellular infiltration, epithelium loss and/or muscular necrosis (Grades 2-4).

In the fornix, lesions were observed in the epithelium as the epithelial cell vacuolization, espongiosis, loss of epithelium with basal membrane exposure, accumulation of lymphocytes, and muscular necrosis. In the vagina, vulva and clitoris there were very severe lesions, compatible with the macroscopic observations, which are characteristics of the GVS (Table VI). Histopathologic examination of the vaginal lesions showed epithelial necrosis and severe infiltration, large number of degenerative neutrophils and foamy macrophages, and vascular proliferation in the submucosa.

\section{DISCUSSION}

Genital ureaplasmosis is frequently overlooked in dairy and beef cattle, despite the presence of vesicles and/or petechiae in the vaginal mucosa. In the present study the VLS, verified in vivo, was evaluated considering the size and aspect of the granules, as well as the presence of hyperemia and extension of the lesions on the mucosa. In this context, the VLS 2 describes the chronic form of GVS, as previously reported (Doig et al. 1979), and this was the more frequent condition in the heifers (42.1\%), positive only for Ureaplasma diversum and slaughtered. The absence of other macroscopic lesions in the reproductive tract, as tissue damages, malodorous secretion on the mucosa, and the
TABLE IV

Distribution of microscopic lesions in the uterus (uterine horns and body) of heifers with GVS and presenting positive culture for Ureaplasma diversum.

\begin{tabular}{cccc}
\hline \multirow{2}{*}{$\begin{array}{c}\text { Lesion } \\
\text { Grade }\end{array}$} & \multicolumn{3}{c}{$\mathbf{N}^{\mathbf{0}}(\%)$} \\
\cline { 2 - 4 } & Uterine Horn \\
\cline { 2 - 4 } & Anterior & Medial & $\begin{array}{c}\text { Uterine } \\
\text { Body }\end{array}$ \\
\hline 0 & - & - & - \\
1 & - & - & - \\
2 & - & - & $1(6.7)$ \\
3 & - & - & - \\
4 & $28(100)$ & $33(100)$ & $14(93.3)$ \\
Total* & 28 & 33 & 15 \\
\hline
\end{tabular}

*Total of evaluated fragments in each segment.

TABLE V

Distribution of microscopic lesions in the cervix (uterine, medial and vaginal) of heifers with GVS and presenting positive culture for Ureaplasma diversum.

\begin{tabular}{ccc}
\hline Fragment & $\mathbf{N}$ & Means \pm SEM \\
\hline Uterine & 18 & $3.5 \pm 0.3$ \\
Medial & 16 & $3.0 \pm 0.4$ \\
Vaginal & 15 & $2.9 \pm 0.4$ \\
Total & 49 & \\
\hline
\end{tabular}

TABLE VI

Distribution of microscopic lesion score in the fornix, cranial vagina and vulva of heifers with GVS and presenting positive culture for Ureaplasma diversum.

\begin{tabular}{|c|c|c|c|}
\hline \multicolumn{2}{|c|}{ Fragment } & \multirow{2}{*}{$\frac{\mathbf{N}}{18}$} & \multirow{2}{*}{$\begin{array}{c}\text { Means } \pm \text { SEM } \\
2.7 \pm 0.3\end{array}$} \\
\hline & Right & & \\
\hline romind & Left & 15 & $2.9 \pm 0.3$ \\
\hline Vagina & & 16 & $3.0 \pm 0.3$ \\
\hline \multirow{2}{*}{ Vulva } & Right & 18 & $2.4 \pm 0.2$ \\
\hline & Left & 16 & $2.6 \pm 0.3$ \\
\hline Clitoris & & 18 & $2.9 \pm 0.3$ \\
\hline Total & & 101 & \\
\hline
\end{tabular}

negative microbiological cultures suggest that the resolving process of the acute phase, immediately post infection, has passed.

Regarding the microscopic evaluation of the uterine tube, it was verified that all portions showed some tissue damage that might prejudice 
the reproductive process. The ureaplasmal effects on the uterine tube between 10 and 24 hours after experimental infection were reported (Stalheim et al. 1976) as epithelial desquamation, presence of clots and chromatin marginalization of the submucosa cells, cilia curvature, clots and irregular nodules on epithelial surface followed by deciliation, projection of cytoplasm until the vacuolization of secretory and ciliated cells, and finally with disorganization of the epithelium, necrosis, and desquamation, around 144 hours after exposition. A peculiar characteristic of the ureaplasmas is to interrupt the ciliary activity and cause severe epithelial lesions in the uterine tube (Stalheim and Gallagher 1977). The ultrastructural alterations of the secretory epithelium harm the oocyte maturation and the early embryo development (Bage et al. 2002). Additionally, the integrity of the isthmus seems to be essential for fertilization, since that is a local of spermatozoa storage, and also where the male gamete effectively acquires the fertilization ability, due to the secretion of specific substances by the epithelial local cells (Scott 2000, Bosch and Wright 2005, Gábor et al. 2008). The results of the present study show that ureaplasma infections harm the ciliated cells and, in some cases, destroy completely the epithelium (Figure 1), impairing its facilitator activity to the migration of gametes to the fertilization place, as well as of the embryo to the uterus.

In bovines the regulation of the estrous cycle is directly dependent on the endometrial integrity, once this portion is responsible for the hormonal regulation of the estrous cycle through $\mathrm{PGF}_{2} \mathrm{a}$ and $\mathrm{PGE}_{2}$ (Krzymowski and Stefanczyk-Rzymowska 2008). In this study $100 \%$ of the uterine fragments (uterine horns and body) showed lesions scored as 4 , with presence of four or more inflammatory alterations, besides the epithelium destruction and/or muscular necrosis (Figure 2, Panel a, b, d). The presence of mononuclear cells and glandular damage in the endometrium in repeat breeding cows was correlated with the presence of Ureaplasma diversum in the herd (Galindo et al. 2004, Oliveira Filho et al. 2005).

Under an inflammatory situation the uterus releases $\mathrm{PGI}_{2}$, a potent inhibitor of erythrocytes aggregate and an activator of veins dilatation. Additionally, ureaplasmas release phospholipases, which alter the prostaglandin synthesis from the araquidonic acid. Since the largest source of $\mathrm{PGI}_{2}$ is the capillary, in the not injured endometrium the $\mathrm{PGI}_{2}$ increases the local irrigation, favoring, probably, the neutrophils emigration, but in the presence of lesions this function is decreased (Moncada 1982, Kucharski and Jana 2005). Kim et al. (1994) reported that $U$. diversum was able to alter the production pattern of $\mathrm{PGE}_{2}$ and $\mathrm{PGF}_{2}$ a without modifying the viability of those cells; but present results suggest that studies should be conducted to evaluate how the continuous exposition to the bacteria can alter uterine function.

Since ureaplasmas do not have rigid cell wall and requires a microaerophilic environment to grow, the survival of these organisms is compromised in the uterus. This condition was reported (Gale 1987), and the author did not obtain positive isolations for Ureaplasma diversum of uterine content, even after infecting heifers experimentally. Then, after the reintroduction in the uterus during more favorable periods, such as the estrous cycle, when the cervix is open, or during artificial insemination, Ureaplasma diversum seeks integral cells to parasite, since the adherence and the parasitism of the epithelium cells are essential conditions for its survival. Thus, its local effect happens, probably, not through a multiplication mechanism, like other opportunist organisms, but because the constant re-contamination. Uterine inflammation was associated with the production of pro-inflammatory cytokines in the parenchyma after experimental infection with Ureaplasma diversum in mices, but changes in tissue morphology or evidences of acute inflammatory response were not present (Silva et 


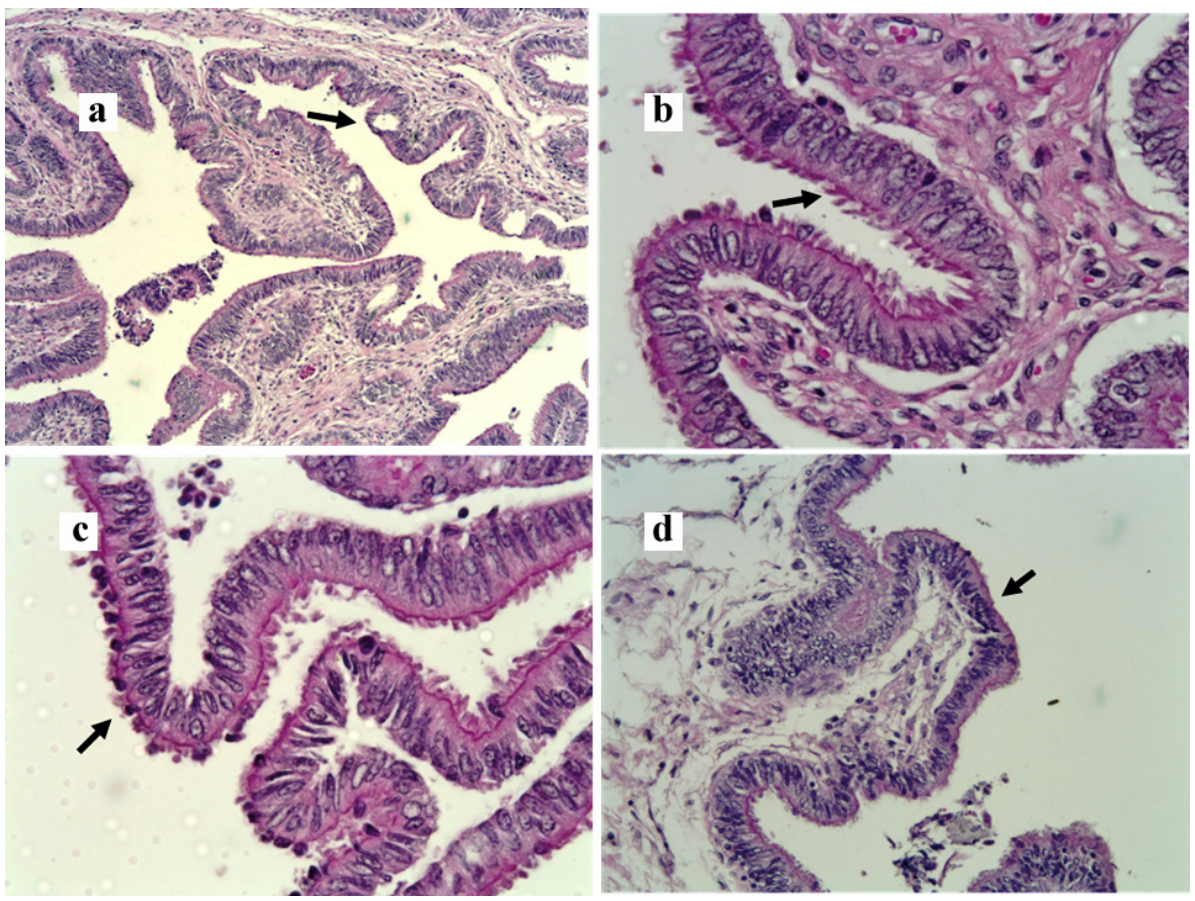

Figure 1 - Photomicrography. Uterine tube. Panel a- infundibulum, intraepithelial vesicles (narrow, H\&E, 200X); Panel b- Infundibulum, curvature of cilia (narrow, H\&E, 400X); Panel cAmpola, decilition (narrow, H\&E, 200X); Panel d- Isthmus, epithelial cells with cytoplasmatic projection (narrow, $\mathrm{H} \& \mathrm{E}, 400 \mathrm{X}$ ).

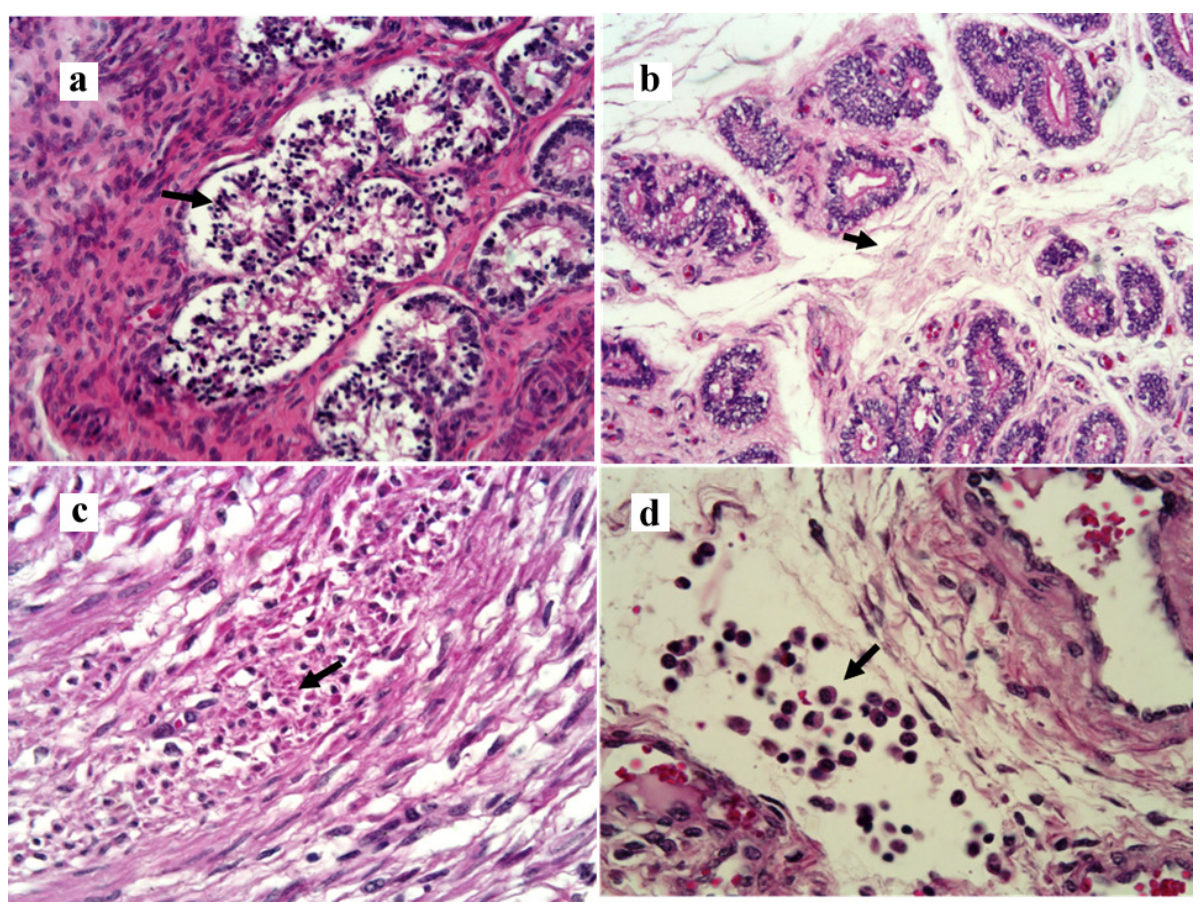

Figure 2 - Photomicrography. Panel a- Uterus, destruction of glandular epithelium and infiltration of lymphocytes (narrow, H\&E, 200X); Panel b- Edema of uterine submucosa (narrow, H\&E, 200X); Panel c- Cervix, muscular necrosis and eosinophils (narrow, H\&E, 400X); Panel dUterine submucosa, focal PMN infiltration (narrow, H\&E, 400X). 

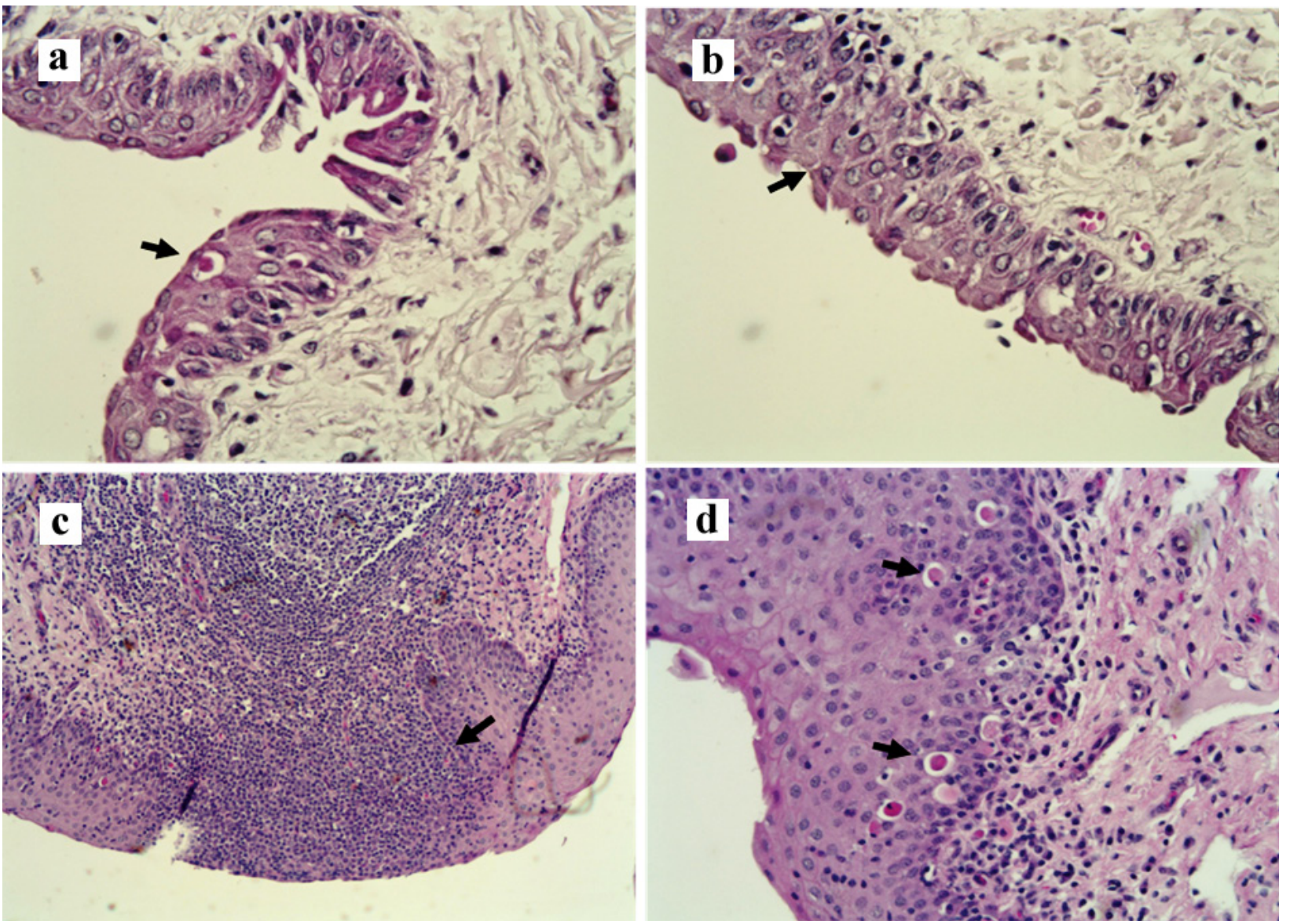

Figure 3 - Photomicrography. Panel a- Fornix, disceratosis in the epithelial cells (narrow, H\&E, 400X); Panel b- Fornix, spongiosis, discrete epithelial atrophy, congestion of the lamina propria (narrow, H\&E, 400X); Panel c- Vulva, submucosal diffuse infiltration of lymphocytes - exocitosis (narrow, H\&E, 100X); Panel d- Vulva, disceratosis in the epithelial cells (narrow, H\&E, 400X).

al. 2016). Since in the present study it was found that most of the heifers had VLS 2, compatible with a cronic local infection, the uterine tissue damage might be related to the constant re-infection, as previously discussed.

Cervicitis is associated to genital ureaplasmosis (Husted 2003). Cervical damage alters $\mathrm{pH}$ of local mucus and provides an adverse environment to spermatozoa survival. Considering that the cervical epithelium contains cells with high glandular activity, and that the irregular outline with crypts increases the surface of a restricted area and maintains the production of a mucus rich in important proteins acting in the sperm transport, injured local tissue compromises directly the fertilization ability of the gamete, since these cells have the responsibility of releasing glycosaminoglycan involved in the acrosome reaction (Lee and Ax 1984). The accumulation of eosinophils and leukocytes with lesion of the columnar ciliated epithelium in the cervical mucosa of studied samples (Figure 2, Panel c) suggests the activation of the host immune system, and its presence may signalize the activation of the chemotaxis mechanism during frequent reexposure to the agent.

A previous study showed that one third of samples collected from the fornix of females, which vaginal content were positive for $U$. diversum was also positive, indicating favorable conditions 
to the bacteria survival (Petit et al. 2008). In the present study no fornix sample was positive for Ureaplasma diversum or other microorganism, and lesion scores of this anatomical region was lower than those of uterine tube, uterus and cervix, with higher number of fragments with leukocyte infiltration [(more evident in recent infections), Figure 3] than epithelial damages or tissue necrosis, which characterize older lesions.

Histopathological founds of the present study showed severe lesion scores in the fragments of vagina and vulva, with characteristics of acute inflammation. Vulvovaginitis is be periodically observed in heifers or cows positive for Ureaplasma diversum (Cardoso et al. 2000), resulting in infertility. The contact between the mucosa of vagina and penis, as well as the friction during mating cause a break of the vesicles, resulting in the semen and male contamination (Miller et al. 1994).

In conclusion, the results here described show that the histopathological findings of the reproductive tract of heifers naturally infected by Ureaplasma diversum are compatible with lesions that compromise the reproductive process, since the spermatozoa ability to fertilize the oocyte, the embryo implantation until the pregnancy maintenance. Therefore, animals with GVS must be identified in the herd, because besides favoring the reduction in the fertility rates, they might be a silent source of Ureaplasma diversum.

\section{ACKNOWLEDGMENTS}

Authors would like to thank the owner and herdsmen of Fazenda Santa Rosa for their help. This study was partially supported by the Conselho Nacional de Desenvolvimento Científico e Tecnológico (CNPq) of Brazil, contract n.478716/2006-0. M.L. Gambarini was supported by CNPq.

\section{REFERENCES}

AHMADI MR, NAZIFI S AND GHAISARI HR. 2006. Comparision of hormonal changes of estrous cycle with cytology of cervical mucosa and hematological parameters in dairy heifers. Comp Clin Path 15: 94-97.

AZEVEDO JB, SILVA GS, ROCHA PS, PITCHENIN LC, DUTRA V, NAKAZATO L, DE OLIVEIRA AC AND PESCADOR CA. 2017. Presence of Ureaplasma diversum in the genital tracts of female dairy cattle in Mato Grosso State, Brazil. Trop Anim Health Prod 49: 311-316.

BAGE R, MASIRONI B, SAHLIN L AND RODRIGUEZMARTINEZ H. 2002. Deviant peri-oestrual hormone patterns affect the epithelium of the uterine tube in repeatbreeding. Reprod Fert and Dev 14: 461-469.

BELL MJ AND ROBERTS DJ. 2007. The impact of uterine infection on a dairy cow's performance. Theriogenology 68: 1074-1079.

BOSCH P AND WRIGHT RW. 2005. The oviductal sperm reservoir in domestic mammals. Arch Med Vet 37: 95-104.

CARDOSO MV, SCARCELLI E, GRASSO LMPS, TEIXEIRA SR AND GENOVEZ ME. 2000. Ureaplasma diversum and reproductive disorder in Brazilian cows and heifer; first report. Anim Reprod Sci 63: 137-143.

CHEŁMOŃSKA-SOYTA A, KATSKA L, KURPISZ M, STEFANIAK T AND ZIMECKI M. 2001. The effect of Ureaplasma diversum activated mononuclear leukocytes on the development and interferon-tau production by bovine IVF-derived embryos. J Reprod Immunol 51: 145158.

CUNHA RAF, TAKIMOTO S AND TAKEI K. 1987. Modificação e padronização de meios de transporte e cultivo de Mycoplasmas genitais: Mycoplasma hominis e Ureaplasma urealyticum. Rev Farm Bioquím Univ São Paulo 23: 170-177.

DOIG PA, RUHNKE HL, MACKAY AL AND PALMER NC. 1979. Bovine granular vulvitis associated with ureaplasma infection. Can Vet J 20: 89-94.

GÁBOR G, TÓTH F, ÓZSVÁRI L, ABONYI-TÓTH ZS AND SASSER RG. 2008. Factors influencing pregnancy rate and late embryonic loss in dairy cattle. Reprod Dom Anim 43: 53-58.

GALE SP. 1987. The effects of two Ureaplasma diversum strains on early pregnancy in Heifers. Can J Vet Res 51: 536-538.

GALINDO ASD, GAMBARINI ML, OLIVEIRA FILHO BD, GALINDO JÚNIOR TL AND KUNZ TL. 2004. Avaliação histológica do endométrio de vacas leiteiras repetidoras de estro (Endometrial histological evaluation of repeat breeders dairy cows). Rev Bras Reprod Anim 28: 132-136.

GAMBARINI ML, KUNZ TL, OLIVEIRA FILHO BD, PORTO RNG, OLIVEIRA CM, BRITO WM AND VIU 
MA. 2009. Granular vulvovaginitis syndrome in Nelore pubertal and post pubertal replacement heifers under tropical conditions: role of Mycoplasma spp., Ureaplasma diversum and BHV-1. Trop Anim Health Prod 41: 14211426.

HOBSON N, CHOUSALKAR KK AND CHENOWETH PJ. 2013. Ureaplasma diversum in bull semen in Australia: its detection and potential effects. Aust Vet J 9: 469-73.

HUSTED JR. 2003. Bacterial and fungal organisms in the vagina of normal cows and cows with vaginitis. Texas A \& M University. Houston. Dissertation (Meister of Science), $90 \mathrm{p}$.

JEON SJ ET AL. 2016. Uterine Microbiota and Immune Parameters Associated with Fever in Dairy Cows with Metritis. PLoS ONE 11: e0165740.

KIM JJ, QUINN PA AND FORTIER MA. 1994. Ureaplasma diversum infection in vitro alters prostaglandin $\mathrm{E}_{2}$ production by bovine endometrial cells without affecting cell viability. Infect and Immun 62: 1528-1533.

KRZYMOWSKITAND STEFANCZYK-KRZYMOWSKA S. 2008. The role of the endometrium in endocrine regulation of the animal oestrus cycle. Reprod Dom Anim 43: 80-91.

KUCHARSKI J AND JANA B. 2005. Immuno-endocrine mechanisms connected with the creation of corpora lutea persistent in animal ovaries. Pol J Vet Sci 8: 255-259.

LEE CN AND AX RL. 1984. Concentrations and composition of glycosaminoglycans in the female bovine reproductive tract. J Dairy Sci 67: 2006-2009.

LUNA LG. 1968. Manual of histologic staining methods of Armed Forces Institute of Pathology, $3^{\text {rd }}$ ed., New York: Mc Graw-Will, 258 p.

MARTINS CF, VASQUES L, NEIS F, TARDIN M, VISIOLY V AND FERNANDES CE. 2002. Biópsia endometrial em vacas Bos Indicus em regime extensivo de criação com problemas de fertilidade. Ensaios e Ciência 6: 13-33.

MATEUS L, LOPES DA COSTA L, BERNARDO F AND ROBALO SILVA J. 2002. Influence of puerperal uterine infection on uterine involution and postpartum ovarian activity in dairy cows. Reprod Dom Anim 37: 31-35.

MILLER R, CHELMONSKA-SOYTA A, SMITS B, FOSTER R AND ROSENDAL S. 1994. Ureaplasma diversum as a cause of reproductive disease in cattle. Vet Clin North America. Food Anim Pract 10: 479-490.

MONCADA S. 1982. Prostacyclin and arterial wall biology. Arteriosclerosis, Thrombosis, and Vascular Biology 2: 193-207.

OLIVEIRA FILHO BD, PORTO RNG, GAMBARINI ML, KUNZ TL, FERRAZ HT, VIU MA, LOPES DT AND SOUSA APF. 2005. Isolamento do Ureaplasma diversum em muco vulvovaginal de vacas leiteiras repetidoras de estro no estado de Alagoas - Brasil. Arch Vet Sci 10: 151156.

PENG Y, WANG Y, HANG S AND ZHU W. 2013. Microbial diversity in uterus of healthy and metritic postpartum Holstein dairy cows. Folia Microbiol (Praha) 58: 593-600.

PETIT T, SPERGSER J, AURICH J AND ROSENGARTEN R. 2008. Prevalence of Chlamydiaceae and Mollicutes on the genital mucosa and serological findings in dairy cattle. Vet Microb 127: 325-333.

RUHNKE HL AND ROSENDAL S. 1994. Useful protocols for diagnosis of animal mycoplasmas. In: Whitford HW et al. (Eds), Mycoplasmosis in Animals: Laboratory Diagnosis. Iowa State University Press, Ames, Iowa, p. 141-144.

SCOTT MA. 2000. A glimpse at sperm function in vivo: sperm transport and epithelial interaction in the female reproductive tract. Anim Reprod Sci 60-61: 337-348.

SILVA JR, FERREIRA LFAA, OLIVEIRA PVS, NUNES IV, PEREIRA IS, TIMENETSKY J, MARQUES LM, FIGUEIREDO TB AND SILVA RAA. 2016. Intra-uterine experimental infection by Ureaplasma diversum induces TNF-alpha mediated womb inflammation in mice. An Acad Bras Cienc 88: 643-652.

STALHEIM OHV AND GALLAGHER JE. 1977. Ureaplasmal epithelial lesions related to ammonia. Infect and Immun 15: 995-996.

STALHEIM OHV, PROCTOR SJ AND GALLAGHER JE. 1976. Growth and effects of Ureaplasmas (T Mycoplasmas) in bovine oviductal organ cultures. Infect and Immun 13: 915-925.

WINSTAT. 2006. User's manual WINSTAT ${ }^{\circledR}$ for EXCEL. R.Fitch Software, Bad Krozingen, 131 p.

YOU X, ZENG Y AND WU Y. 2006. Interactions between Mycoplasma lipid-associated membrane proteins and the host cells. J Zhejiang Univ SCIENCE B 7: 342-350. 